\title{
Arte Povera as a Tool in Critical Italian-Language Pedagogy
}

\author{
Giuseppe Formato \\ Lesley University, United States \\ E-mail: gformato@lesley.edu
}

Received: July 2, 2020

Accepted: August 13, 2020

Published: August 24, 2020

doi:10.5296/ijl.v12i4.17423

URL: https://doi.org/10.5296/ijl.v12i4.17423

\begin{abstract}
Visual arts are culturally and historically significant to Italy and a reason why many people study the Italian language. This significance is visible in Italian-language classes, from mentions of high art in beginner-level textbooks to entire courses taught in advanced-level Italian devoted to these arts and their respective movements. The importance of these works to art history and to humanity at large cannot be denied relative to learning about Italian culture in the classroom. However, as presented in this literature review, it may be useful to reevaluate how these more traditional teaching subjects can be considered neutral, with a heavy emphasis on instruction as well as a subconscious perpetuation of racist, sexist, and capitalist ideals. By instead drawing upon the contemporary Italian Arte Povera movement a tool of critical pedagogy from beginner to advanced Italian-language courses, Italian art culture and language can be taught by using a more political, multidimensional approach focused on the learners' contexts and histories. Thus, students may better understand themselves through Italian language and foster critical thinking, in addition to ultimately acquiring the language.
\end{abstract}

Keywords: Italian language, Critical theory, Critical pedagogy, Arte Povera

\section{Introduction}

Interest in studying Italian can range from enrollment in a single undergraduate elective to years of study minoring or majoring in Italian language. Reasons for study vary, but a strong connecting factor is a general curiosity about Italy's culture (Drakouli et al., 2013). Italy is undeniably rich in what is considered high culture, most apparent in Italy's cultural visual-art contributions to world heritage, such as Renaissance period arts. Evidence of this interest is found in advanced courses taught exclusively in Italian about the high arts and in 
beginner-level language classes (Stebaieva, 2018), whose textbooks include images of Italy's most recognizable artistic treasures, such as Michelangelo's David and Botticelli's La Primavera. The importance of these works and their contribution to humanity is clear. However, their presence and strong emphasis in the language-learning classroom arguably perpetuate axioms of Italian cultural void of opportunities for critical discussion about heteronormative ideas of beauty, the natural world, and traditional definitions of wealth and success (Formato, 2018). The Italian language-learning classroom thus presents a lacuna in research on strategies for language teaching or materials through a critical lens on Italy's rich cultural heritage of the arts.

Critical theory addresses society dialectically by analyzing political economy, domination (Gramsci \& Rosengarten, 2011), exploitation, and ideologies (Horkheimer \& O'Conner, 2002). These theories extend to the classroom via critical pedagogy as an offshoot within the education field and serve as a teaching approach. Critical theory attempts to help students question and challenge the dominant beliefs and practices (Freire, 2000) that the culture industry has presented (Horkheimer et al., 2002)—often subconsciously (Giroux, 2001) - through images and even through art. Thus, the language-learning classroom can be a valuable arena in which to instruct foreign language in a way that is not politically neutral but critical consciousness (Abednia, 2015).

One art movement born in Italy but entirely overlooked in Italian-language instruction is Arte Povera. This contemporary art movement of the 1960s and 1970s took a radical stance on Italian government, industry, and culture. It brought to the forefront a challenging confrontation with man's relation to nature and society and a rejection of capitalist culture (Celant, 2008). Such critical stances offer the viewer important perspectives for paradigm shifts within the lens of Italian culture.

Despite advancements in pedagogical technologies and similar considerations, there remains a dearth of research on critical pedagogy in the Italian-language classroom, particularly regarding teaching methods. The intent of this paper is to demonstrate the relevance of the Arte Povera movement to the field of Italian-language pedagogy, from beginner to advanced levels (Diez, 2009). With these purposes in mind, the paper addresses how theoretical underpinnings from the Arte Povera movement can be used in Italian language and culture pedagogy. It argues that Arte Povera artworks offer new insights and paradigms for the Italian language instructor as a means of critical language pedagogy through the arts.

\section{Methodology}

The literature in various fields was analyzed as they related to (1) Arte Povera and its relevant concepts and styles, (2) critical theory and cultural hegemony, and (3) critical pedagogy and critical language pedagogy. Sources ranged from unpublished theses to seminal works in books and peer-reviewed articles in international scholarly journals. Narratives used in this review were chosen based on their relevance not only to developing a critical means of using art to teach language and culture, but also to presenting Arte Povera and language teaching in a historical perspective. I read and reread relevant articles within each field with the aim of determining key articulations and clusters of relevancy to construct a framework applicable to 
acquiring Italian. I reviewed the data to identify both consensus with and areas of uniqueness between my experience and collected memos as a university-level Italian language instructor. One significant analytic strategy used was memoing, in which I constructed a conceptual bridge between the written research and concepts used. I kept an audit trail that recounted my thinking and recorded the basis for my choices during the research process using a journal (Merriam et al., 2016), as well as documenting memos. In addition to these thorough records of how I examined and came to understand the data, I reflected on my experiences as a instructor (Lincoln \& Guba, 2000). Consensus across these multiple areas ultimately led to the paradigm of considering how Arte Povera could be a tool for achieving critical language pedagogy while learning Italian, as presented in the next sections.

\section{Literature Review}

\subsection{Arte Povera}

In contrast to the high arts of Italian cultural history, Arte Povera was a radical contemporary art movement. Its avant-garde artists utilized a range of unconventional processes and nontraditional, everyday materials (Vergine, 2001).

\subsubsection{The Movement}

Literally meaning "poor art," the Arte Povera movement was popular between the 1960s and 1970s in Italy, particularly in Turin, Milan, Genoa, and Rome. Art curator and critic Germano Celant first used the term arte povera in 1967. During the radical protests of that time, artists throughout Italy challenged the traditional values of mainstream culture that for centuries had dominated industry, government, and culture in general (Malloy, 2003). These protests occurred within an era of economic volatility for Italy. Celant's (1967) use of the word "poor" did not signify lack of wealth but referred to the movement's unifying component, in which artists utilize commonplace materials that greatly contrasted with those of great artworks of the past, such as marble, oil paint on canvas, or bronze (Krauss, 2008).

The movement touches upon many concepts and trends, including a return to simple objects and messages: body and behavior as art, everyday becomes meaningful, nature and industry are suggested, complex and symbolic signs lose meaning, and notions of space and language are explored. Notable pieces came from the distinction of organic materials, which suggest the appearance of consumer culture (Christov-Bakargiev, 2014). Deeming that modernity endangered collective memory and ritual-both important components of Italian culture-Arte Povera sought to differentiate between the old and new to obscure the perception of time.

Its artists also rejected what they identified as scientific rationalism. In contrast to American minimalisms methodical, almost-clinical approach to spatial relations, Arte Povera invoked a realm of fiction whose obscurities could not be clearly explained (Pinkus, 2009). Arte Povera artists produced bizarre, shocking, and amusing contrasts, often juxtaposing the pre-industrial and the processed. They sought to disrupt and reject the values of a commercialized, capitalist world by evoking the pre-industrialist time (Bennett, 2008). They challenged established beliefs of value and propriety and subtly critiqued Italy's industrialization and mechanization. 
In this way, Arte Povera artists conjured consequences of modernization, including its propensity to devastate practices of memory and locality as it continued towards the future (Cullinan, 2008). They used rags, rocks, clothing, twigs, plastic, dirt, and rope to confront and defy Italy's traditional artistic past and the hegemonic cultural norms they embodied.

Arte Povera arose during a decline in Italian abstract painting and increased attention to previous avant-garde approaches to creating art, such as surrealism. Its beginnings can be traced to Alberto Burri, Piero Manzoni, and Lucio Fontana. Burri's works, largely made from burlap sacks, exemplify using poor materials as an avant-garde approach to create abstract pieces on canvas (Hamilton, 2008). Manzoni's work foreshadowed qualities of conceptual art. It reacted against abstract painting by applying uncomplicated concepts and amusing subversion to question the frontiers of traditional practices (Mansoor, 2001). His most notorious work entailed cans of his own excrement, which he sold by weight to collectors at a price equivalent to gold. This shocked the art world but showed the unlimited potential of the basest materials to critique society.

These works inspired other notable artists of the Arte Povera movement, among them Giovanni Anselmo, Alighiero Boetti, Jannis Kounellis, Marisa Merz, Giulio Paolini, Pino Pascali, Giuseppe Penone, and Michelangelo Pistoletto. Creating large- and small-scale pieces, these artists each attacked commercialism in different ways as they sought to use unconventional materials and styles (Bottinelli, 2015).

Their work demonstrated a response against the modernist abstract painting that had overshadowed European art in the 1950s (Gilman, 2008). They differentiated themselves by focusing more on sculptural work than painting. Arte Povera also rejected American minimalism, especially that movement's enthusiasm for technology and control over the art world. Resisting modernism and technology, Arte Povera's traces of the past have distinctly Italian aesthetics and qualities (Veikos, 2006).

Celant (1967) coordinated the movement's first survey, "Arte Povera e Im Spazio," staged at Galleria La Bertesca in Genoa. Overall, he emphasized the interference of trivial, everyday materials into the art sphere, pressing its onlookers to consider insignificant material in a new way. Celant then authored "Arte Povera: Notes for a Guerilla War," a manifesto that defined the movement's frontiers, describing a wider ranging Arte Povera movement than before (Galimberti, 2012). For example, Pistoletto's mirror pieces included photography components, a method that other Arte Povera members had not used. Notes for Celant's "Guerilla War" connected the artists theoretically through what Celant saw as their shared aspiration to obliterate "the dichotomy between art and life," exposing the artists' radical motivation and persistence on different forms of society as the termination of the art-life margin (McKee, 2013)

\subsubsection{Concepts and Styles}

The use of dirt, food, water, and inexpensive construction materials juxtaposed with the industrial sensibilities of American minimalism, which the artists viewed as unsuitable to Italy's cultural atmosphere after World War II. In their quest to rejoin art with life, Arte 
Povera artists endeavored to incite an intimate reaction to each of their works, accentuating a unique interface between spectator and object.

Sculpture is the creative medium most strongly linked with Arte Povera. Stemming from their refusal of conceptual and minimalist painting styles, artists produced objects that needed contact with the viewers. For example, Anselmo's 1968 Untitled required the gallery to continually replace the lettuce at the center of the sculpture. Pistoletto's (1965-1966) Minus Objects obliged the viewer to manipulate the object and fill the sculpture's void to thereby assign it meaning. Artists also endeavored to link the natural and the synthetic (Cullinan, 2011). For example, water and dirt might be presented but restricted by geometric structures. These disparate materials also can be seen in the contrast of industrial practices with human waste. Thus, the artists drew attention to the ambiguities intrinsic in the system that placed importance on art objects and the gallery room itself.

The Arte Povera movement disbanded in the mid-1970s as the artists' individual styles diverged. In recent decades, it has resurged in popularity (Gilman, 2008). Its influence as conceptual art has endured internationally through other art movements. In North America, for instance, post-minimalism and anti-form refer to works that reject the static industrial forms and sleek shapes of minimalist sculpture. In Japan, the mono-ha group investigated the fundamental nature of materials and distanced itself from technological modernism.

\subsection{Critical Theory/Cultural Hegemony}

Gramsci (2014) asserted that with technological progress, social management is implemented less through physical control than through diffusion of a complex structure of principles and needs. The latter conveyed to institutional authority an evident level of legitimation and universality. Gramsci et al. called this type of control "ideological hegemony," a process that influenced opinion and constructed the daily habits that create performance. Ideological hegemony described structures of methods, implications, and ideals that offer authenticity to the prevailing society's institutional arrangements and concerns (Giroux, 2011). Gramsci's (2014) assessment offers a theoretical groundwork for social and cultural propagation because it replicates social practices supplied in pedagogical spaces.

Education and curricula assessments founded on positivist understandings of knowledge tend to make solid claims of neutrality and empirical substantiation of facts without inquiring into the nature of knowledge, truth, or the social, cultural, and political welfares of diverse knowledge claims (Abednia, 2015). The notion that facts, theory, and inquiry can be verified and used only quantitatively is vulnerable to conservative ideals. Incapable of reflecting on its own assumptions or offering critical reflection in general, it ends up uncritically sympathetic to the status quo. In the positivist context, rather than understanding the world holistically as a system of interconnections, learners are instructed to arrive at questions as though they occurred in isolation from the social and political powers that offer them significance. This approach generates a tunnel vision in which only a minor sector of social existence is accessible for analysis (Giroux, 2011). 
In response to the escalation of fascism and Nazism and the failure of orthodox Marxism, the Frankfurt School philosophers tackled concepts encompassing control and emancipation from a different perspective. They emphasized how the realm of culture and daily life represents a new field of control (Giroux, 2016). Like Nietzsche's (1876/2015) caution regarding individuals' blind devotion to reason, Adorno and Horkheimer criticized modernity's unwavering trust in the Enlightenment's promise of rationality to rescue the world from ignorance, fantasy, and despair. They understood that the advancement of reasoning had permeated all aspects of daily life, from mass media to education (Kalekin-Fishman \& Langman, 2015). The tragedies of rationale arise as society becomes more rationalized because it misses its critical capability to achieve social harmony (Adorno, 2007) and become an instrument of society, thus deeming criticisms irrational (Giroux, 2011). Those correlated with the Frankfurt School called for dialectics in theory. They wished to bring about critical thinking and expose deficiencies and weaknesses in what conventional society deemed a completed structure of thinking (Held, 2006). For Frankfurt School philosophers, rationalism was no longer simply the practice of critical thinking but a juncture of action, emancipation, and society (Giroux, 2011). A more critical interpretation of knowledge would explain it as a social construct associated with human intentionality and behavior.

Deciphering this viewpoint into pedagogical values, the idea of knowledge must connect to the notion of power (Giroux, 2011). This implies that classroom knowledge can be used in the interest of either dominance or freedom (Greene, 2018). It can be a critical means to interrupt erroneous reasoning or unreflectively legitimize explicit interests that appear value free and unsusceptible to critique.

\subsection{Critical Pedagogy}

Traditional pedagogy readies learners to enter social environments, whereas critical pedagogy prepares them to oppose, reconsider, reflect, and transform in response to social disparity. Critical pedagogy implies instruction methods that inform power or social stratification (Johnson \& Randolph, 2015). A founding voice of critical pedagogy, Freire (2005) used the word conscientization to illustrate the fostering of a critical consciousness of social reality through contemplation and engagement. This contrasts with his term, banking education, by which the instructor uncritically hands over knowledge rather than centering knowledge as a focal point of critical understanding.

Instruction with a critical lens begins with the key idea that knowledge is socially constructed. Critical pedagogy recognizes that all knowledge is structured in a specific social, cultural, and historical merging of relationships. All proclamations of knowledge reflect the group's concerns and are consumed by power relationships (Abednia, 2015). Knowledge cannot be value free, unbiased, ahistorical, or vague. As a philosophical process, critical pedagogy permits learners to perceive relationships between knowledge, culture, power, and ideology. It endeavors to explore and clarify how knowledge is created and legitimized within the classroom and analytically challenges those types of knowledge in an effort to legitimize suppressed forms and produce new ones (Giroux, 2016). 


\subsubsection{Critical Language Pedagogy}

Crookes (2020) speculated that critical pedagogy is the most wide-ranging form of social justice focused in language instruction. It reframes the study of language teaching, departing from traditional pedagogy that supports the senses students acquired from social conditioning in traditional education. Instead, critical pedagogy attempts to alter learners' meaning positions by resisting education's chief social purpose-inculcating learners with social ideology. Farias (2005) suggested that the notion of critical pedagogy reveals practices pertinent to different language learners. It is constructed on the foundation of knowing how we act as beings and believing in a shared understanding conveyed by language - regardless of the language or our relation to it.

In the language classroom, this foundation increases the learner's consciousness by contemplating language pedagogy as a communal procedure. Because language does not exist outside of its sociocultural environment, critical pedagogy offers language as a critical exercise in self-awareness and commitment to others. It can be integrated into language-learning classrooms (Randolph \& Johnson, 2017), which too often operate as entirely functional, skill-based classes. Instead, instructors take a more critical approach towards teaching in that space. Language study enriches the immigration, inclusion, diversity, and globalization matters that govern our nation's current political atmosphere.

Thus, learners must cultivate their intercultural communicative competence (Randolph \& Johnson, 2017), often a transformative process that profoundly shifts the way learners connect with their world, even within the Italian-language classroom. When partaking in this kind of learning, learners cannot neglect historical and current inequalities. Learners are incapable of effectively participating in the societies about which they learn without also comprehending the societal, historic, commercial, and political circumstances in which they occur.

Instructors cannot educate learners to partake in intercultural communication without expressing an understanding of inequalities within and between the studied populations. Instructors must rid themselves of the one-dimensional model of a speech community and allow learners to develop and examine a multidimensional assessment of history. Teaching history in the target language can be difficult and result in superficial, inaccessible pictures of the history. Thus, instructors frequently present Italian language and culture as a shallow, homogenous entity (Formato, 2018) - for example, thematic units dedicated to streamlined perceptions lauding the worlds of Italian fashion and sports. However, these too often lack a critical standpoint with which to contemplate Italy's culture and history or to question hegemonic concepts embodied within them. Instead, these texts should aim to stimulate learners' critical cultural consciousness by analyzing that culture's - and their own - methods, products, and views through a critically cognizant lens.

It is essential to establish whether and under what conditions critical pedagogy can match Italian-language pedagogy. Learners can confront syntactic structures they do not understand; whether they miscue the discourse's meaning depends on their competence. Incorporating critical pedagogy into communicative language instruction requires reassessing the practice 
of accommodating instances for critical examination into the curriculum, as well as the dialogues for which language-learning is used (Breidbach et al., 2014). The relationship of the learner's language and language being acquired - and the tasks of both for curriculum components - need reevaluation. Critical pedagogical instruction must be supported by a two-sided curriculum: both of conventional language and of dialogue focused on critical analysis issues.

Foreign-language resources usually have a prespecified set of precise, robust objectives and results that are not identified in a critical pedagogy context. Resource designers instead should devise activities to permit instructors and learners to participate in dialogical expansion while they apply language abilities (Rashidi \& Safari, 2011). Then, learners and instructors could uncover cultural principles, beliefs, and values in both the language being analyzed and the learner's primary language to explore the similarities and variations among societies and work to change fundamental disparities (Crookes, 2009). The concerns and issues covered in language-learning materials must create plentiful discussion and analysis of the American culture, the target-language culture, the connection between the two, and other multiplicative themes. The instructor can transform the proposed topics into the language being learned, identify the vocabulary and structures for learners to study, and recommend materials for language acquisition.

Crookes (2009) indicated that linguistic subject matter also may generate cultural points for learners to discover distinctions between first- and target-language constructs and assess their underlying principles. This teaching method engages learners in a succession of reflections and actions through dialogical problem-posing activities. As Crookes suggested, people must act reflectively; pedagogy's mission is to help individuals achieve their human predisposition by incorporating them in a reflection-action sequence, praxis. Learners participate in dialogical problem-posing by first choosing the dialogue's subject and then correlating the issue to their lives (Rashidi \& Safari, 2011). After identifying with the dilemma, the instructor presents questions that critically challenge the learners and, as a decodification, steers them towards dialogue on the issue's socioeconomic, political, or cultural rationales.

Ongoing learner evaluation is a key element of any critical language-learning curriculum (Degener, 2011). Because activities build on learner development, experience, and encouragement, evaluation transforms into a manifestation of a learner's understanding and application of acquisition (Reagan \& Osborn, 2002). An exercise may involve text or images expressing an unfamiliar problem and require learners to share their insights (Rashidi \& Safari, 2011). Foreign-language resources can offer activities to calculate linguistic ability. Crookes (2009) suggested that such activities can expose learners to the level and importance of their intellectual development and growing capability to use the acquired language. Such tasks can establish the reliability of the critical-language pedagogy in use. Language-learning resources should move from designated homework assignments and substitute tasks for learners to collect, select, or produce topics and pedagogical materials. Shifting the learner's role in critical language-learning resources from an idle container to a self-resource also changes the learner's chance of success. Rather than thoughtlessly accepting information to memorize and later repeat, the learner incorporates the language understanding and abilities 
to tackle the subject at hand and independently chooses the topics and linguistic matter (Rashidi \& Safari, 2011).

Crookes (2009) maintained that existing language-learning resources separate the learner from interest and potential to be creative and active in language development. For Crookes, augmented accessibility and collection of resources that help instructors familiarize themselves with critical theories of language learning in critical pedagogy programs could improve the pedagogy's practicality. Currently, instructors have little input into the fundamental tenets essential in resources used for critical language-learning pedagogy.

Foreign-language resources should improve learners' communicative abilities while supporting their critical awareness (Rashidi \& Safari, 2011). Generally, language-learning resources consist of tasks to improve language-learning communicative competences, irrespective of social issues or situations (Reagan, 2006). However, in a critical pedagogy, resources should aim to attain the twofold goal of developing learners' language skills and their knowledge of social frameworks (Hawkins \& Norton, 2009). Hence, the resources' main mission is to permit learners to read the world and not merely the word (Freire \& Macedo, 2016).

Critical pedagogy requires learners to observe the world in unique ways, alter their beliefs, and accept the speaker's perspective (Cardona et al., 2015). For learners of Italian language, acquisition becomes transformative in nature. Transformative learning characterizes the course of reexamining previously held beliefs and expectations and comprehending methods from a new perspective. Viewpoint transformation is the procedure of becoming critically conscious of how and why our standards frame the way we see society-envisioning an all-encompassing view - and letting learners perform based on this new understanding (Mezirow, 2000). Language acquisition is one of the most human actions we can undertake. Coupled with art, another human task, it could transform learners in extraordinary ways that are still understudied in the field of Italian-language pedagogy.

\subsubsection{Art Povera and Critical Language Pedagogy}

Critical pedagogy shares with cultural studies and critical theory its examination of power dynamics and their subsequent social circumstances. Beyond simply acting as a specialized exercise to communicate knowledge or grasp abilities, it frames knowledge in a continuing effort for social justice. Critical pedagogy works on two fundamental notions: the need for a language of criticism and for a language of opportunity that emphasizes human liberation (Giroux, 2005). Critical, ideological, and political meetings with visual and spoken understandings of artworks and visual images of popular culture provide learners that engagement.

Visual art serves as aesthetic, formal, and sociopolitical critique that challenges leading constructs and principles. All artworks have significance, particularly Arte Povera, which is rich in critical subject matter and meaning. It could be argued that the high arts-more aptly, their singular presentation to the exclusion of other movements-perpetuate more conservative, positivist notions of art, its role, and the roles of humans and nature. 
Freire (2005) desired pedagogy concerned with democratizing authority through discussion either explaining circumstances or acting on that interpretation. In that way, the curriculum's existential objective is to support learners to understand their dynamic role in constructing and transforming culture. For Freire, visual art assists in generating learners' new understanding of themselves as dynamic contributors. The arts no longer are disseminated hierarchically according to learners' capacity for words; instead, they are equal to languages (Rancière, 2000). With Arte Povera, new understandings can be generated through the aesthetics of artworks that are challenging and learners likely have never seen. Instead of a language translating the sense of an image, more of the rational becomes discernible. There is no consecutive direction from the presentation of a phenomenon to an appreciation of the state neither of the world nor from rational awareness to political action (Rancière, 2010). Instead, it creates a rift in the association between what is observed and what is considered, between what is thought and what is felt.

Through critical understanding of an artwork, the viewer experiences the interaction among its form, internal content, and external context. This knowledge allows the observer to determine its aesthetic, metaphorical, iconic, or emotional significance within deep visual interpretations. The results offer learners knowledge and occasion to choose options that can add to societal, hence worldwide, well-being.

Art instruction methods that concentrate solely on the formal-such as the Renaissance or high arts of antiquity, even briefly shown in a textbook - and communicative features are distinct from the instrumental style, which acknowledges the visual images' critical and political power and exposes learners to often unseen worlds and concepts. Within this kind of pedagogy, instructors and learners co-create knowledge (Garcia, 2015). This democratic procedure connects learners and instructors in opposing or even uncomfortable critical conversation. Opinions are explained and argued in a forum where only censorship is removed (Hayes, 2020).

Critical pedagogy is a conversational exercise, a discourse wherein narrative, verbal, or visual forms can clarify or describe historically accrued ideals. An instructor's selection of images for analysis is especially crucial; it defines the topic, substance, and politics of the lesson. Many current artworks offer the metaphorical resonance to occasion a focus on topics that spur learners to understand current events - a lived understanding. However, the decision to use this kind of art instruction involves risk (Giroux, 2016) - instead of rejecting the political facet of art instruction, as in value-free education, instructors adopt the political as a constructive way to develop critical awareness. With critical pedagogy combined with the arts, learners and instructors merge the functions of artistic means with political action as they examine ideological structures and all aspects of life.

Pedagogy is biased, socially situated, and created from within ethics and power structures. In the case of Italian-language pedagogy, religious artwork of the past, the automobile and fashion industries, and their associated images perpetuate consumerist and passive thought through cultural exposure in the classroom. They serve the views of those in power and leave learners passively banking items that appear across cultural pedagogy but in fact are void of 
critical thinking. Pedagogies must be disputed when they reject the actual ways that individuals consume and produce culture (Trend, 2012). For this reason, Arte Povera pieces can be used in the classroom because such art modes reject the past, particularly the consumerist and capitalist glories of Italy's fashion industry so often propagated in Italian-language classrooms. Artistic creation as a cultural method that depends on perspective is educative and thus, according to critical pedagogy principles, inseparable from ethical and political issues. Every cultural choice is a pedagogic enterprise (Williams, 1967).

In many equally fortifying aspects, art enlightens social involvement as a pedagogical and political practice. Underscoring the pedagogical in visual art production raises issues as to why some images have more power than others and some creative practices are legitimized and others not. By creating the pedagogical and directive power of visual culture, we can start to express how art is a socially pedagogical process. Art is key to critique. It can illustrate disparities and repressive political, social, and economic matters that critical pedagogy is prepared to address.

Arte Povera has this capability and thus, also must be identified as political. With its critical themes and representations of Italian culture, Arte Povera provides space to welcome the initial disorientating and uncomfortable exposure that allows critical thinking in the language-instruction realm that otherwise would not provide such an opportunity. In critical Italian-language pedagogy, Arte Povera can extend new abilities, develop ethical vision, and involve individuals in methods that provoke challenging issues and new perceptions. Its critical readings can assist reflexive evaluation and views of the social situation and widen viewpoints (Bamisile, 2008).

Arte Povera artworks factor into critical pedagogy in a manner that emphasizes the educative spirit of argument, energy, and politics. This instructive possibility of art, key to critical pedagogy, does not require language instructors to relinquish their influence. Repudiation only conceals - not alters, questions, or moves - authority. The exchange between learners and instructors is directional: seeking answers and making the material significant by responding to the learners' lived experiences. Arte Povera's authority can be viewed as mediation, introducing different viewpoints that promote critical action and agency. To work as an intellectual is to be accountable for one's views and actions. Such accountability is radical because it demands identifying and interfering in power constructions that form the social condition. Arte Povera can challenge those constructions. As a pedagogic exercise, it links discourses formerly held as distinct from conventional didactic matters such as race, gender, and sexuality.

The arts' use, negotiation, dissemination, and social effects form an important element of the pedagogy. Learning in this sense is about not only proficiency, but also understanding and involvement in society. If art is understood as involvement, then it adopts the educative nature of critical thought. Arte Povera can do pedagogic work in what it transmits through its subject matter and how it conveys narratives or anxieties about the nature of art itself. It can incorporate itself in the classroom as a creation method that is directive; it can activate and modify structures of seeing and one's affiliation to the object, self, and society. It links the 


\section{Macrothink}

International Journal of Linguistics

ISSN 1948-5425

2020, Vol. 12, No. 4

question of visual literacy to not only the probability of understanding as an interference in society, but also issues of democracy (Peters, 2016).

\section{Using Arte Povera in the Italian-Language Classroom}

Using art in the language-learning classroom can be an exceptional means to facilitate language acquisition. Art can serve as a valuable tool for language instructors to demonstrate and explain. Learners can use art as a tool to acquire vocabulary and practice language in various contexts. Additionally, because art is inseparable from culture, it can be a point of departure for activities to develop learners' cultural awareness (Žemberová, 2014). By looking at, talking about, reading about, and sharing art, learners can develop and enhance their overall foreign-language skills and vocabulary. For example, an Arte Povera piece, such as Pistoletto's Venus of the Rags (Figure 1), can be used in lower-level courses to identify colors, materials, textures, subject matter, emotions, and contrasts. Intermediate and advanced levels can communicatively discuss more in depth the artwork's subject matter, symbolism, critique of capitalism, psychology, and relationship to the world.

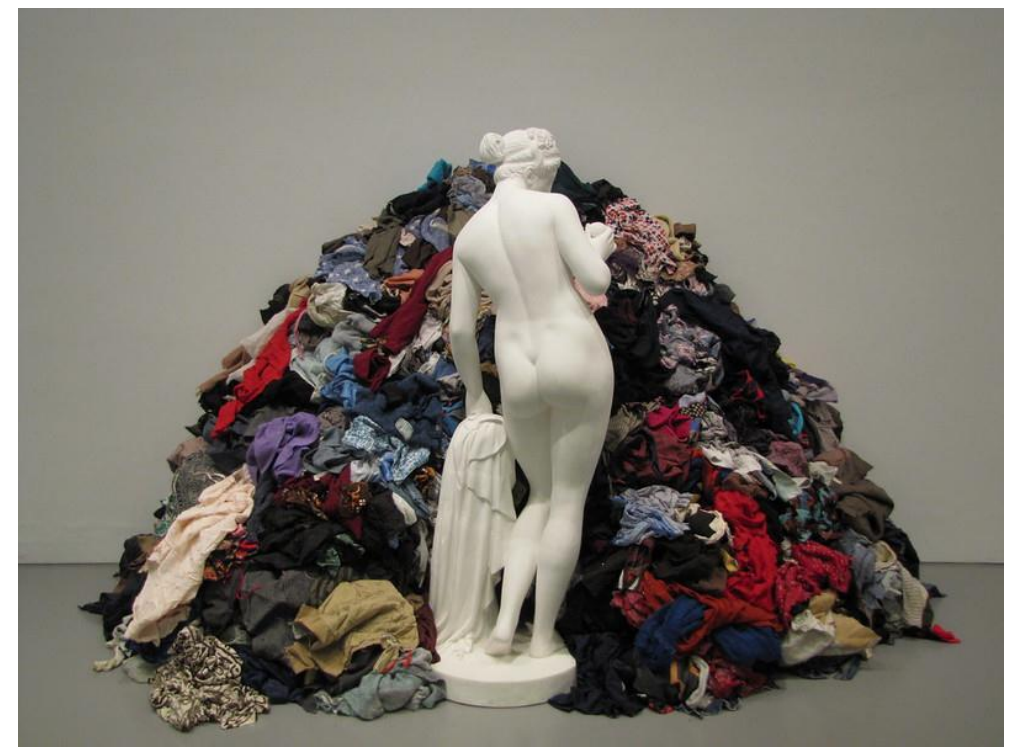

Figure 1. Michelangelo Pistoletto's Venus of the Rags

Photo by rbasallote, https://www.flickr.com/photos/rbasallote/9471596781

\section{Attribution-NonCommercial-NoDerivs 2.0}

However, art is not simply a means for learners to describe what they see in an image. There are many other ways to use art to present new vocabulary and grammatical structures in motivational and interesting ways (Abrantes de Andrade, 2006). The learning emphasis should substitute a content-instruction focus in which learners are urged to acquire knowledge (Román, 2005). This suggests a different paradigm centered on a cognitive model that promotes critical abilities to assist students' critical involvement in their environment (Gude, 2007). 
Art Povera can fit into such a cognitive model: It reconsiders Italian society and culture in a critical perspective through art, thereby questioning cultural beliefs in ways that traditional modes of highly reproduced art cannot. Due to their position in the past and their high rate of reproduction, traditional art modes do not fit an analysis-and-discussion structure that can tackle hegemonic viewpoints.

Arte Povera's multiple layering well positions it in a critical inquiry framework that facilitates the reading of images (Alter, 2011). It deems the aspects around the artwork, such as its public, artist's context, topics, questions, and symbols (Hogan, 2006) to be the critical awareness of core implications and concepts included in the art. Artworks should not be approached simply by traditional deciphering tactics, in which the instructor exposes its connotations, but in a dynamic conversation guided by the instructor.

The language instructor can actively engage learners with images in the learning process (Timuçin \& Aryoubi, 2016), for example, encouraging them to draw on their personal experiences when discussing the images. By placing art within the context of the learners' lives and allowing them to express themselves about the images, language instructors can build on the learners' prior knowledge. In addition to the language and culture they are teaching, instructors can scaffold instruction; connect written with spoken languages; make learning relevant and meaningful; foster higher-order thinking skills; promote high levels of analysis, reasoning, and questioning; support critical and creative thinking; emphasize communicating ideas; and enhance learners' ways of observing, responding to, and representing the world around them. Nowhere is this connection and meaning-making more apparent and possible than in the Arte Povera movement.

Arte Povera could provide the classroom platform to bridge Italian culture with critical thinking and better position learners to the world and the crises within it. Fostering critical thinking through images is crucial because images include concepts about sociocultural issues (Emmison \& Smith, 2000) and, in modern times, largely convey dogmas (Leavy, 2009). The spectator has the capacity to understand images that confirm the concept of supporting a critical observer. The visual arts emphasize that, to promote critical thinking through images, approaches must have a reflective emphasis. This objective can be attained by incorporating visual literacy and a critical inquiry framework around images (Duncum, 2010). The current use and reproduction of, for example, Renaissance or ancient art images in North American Italian-language classrooms does not do this. Lacking a critical frequency framework, it merely perpetuates conventional views of what art and its functions are.

Instructors have a variety of options for using the arts in the language-learning environment. Open-ended questions can draw learners' attention to artwork and be modified for learners' competency levels. The instructor can create a narrative and thematic understanding of the work and connect it to the course's cultural, historic, and ideological content. Pieces from the Arte Povera movement are perfect for open-ended discussions. For intermediate to advanced levels, Pascali's (1967) 32 Meters of Sea can provide an ideal platform to discuss nature, form, and how perceptions may shape views of society in relation to the learners' own lives. 
An arts-integrated university-level curriculum enhances achievement in language skills. The arts can lessen anxiety (Sandemire et al., 2016) and serve as a creative method to boost enthusiasm in the classroom (Strickland, 2008). If learners successfully make connections to their lives, for example through the delineated themes Arte Povera provides, they will feel more connected and thus more enthusiastic. Lowering the affective filter through increased interest (Krashen, 2003) allows language input to enter the brain, ultimately reach the language-acquisition device (Chomsky, 2015), and thereby language acquisition to occur.

The target language is used to discuss art and to extract learners' opinions, thoughts, and feelings. Arte Povera as a movement provides many striking images with themes that provoke and illicit intense discussion and opinion. Learners of Italian language would otherwise not be exposed to such a rich, challenging, and varied viewpoints within the context of Italian culture.

Unfortunately, resources created for the language learner prioritize language over culture (Moeller \& Fatlin Osborn, 2014). If language learning is the lone goal of instruction, then such structured texts fulfill the obvious objective. However, if learning language is about arriving at other cultures through language and rising views, then texts and materials that are more critical are needed (Randolph \& Johnson, 2017).

\section{Conclusion}

Acquainting learners with artworks is an enjoyable feature of authentic learning (Farokhi \& Hashemi, 2011). The arts are a fundamental feature of the human experience. They are vital to liberal social responsibility and deliver a language for forming and articulating comprehension. By inserting Arte Povera into the Italian-language curriculum, learning can become a communication model relative to the learner's increasing capability.

Like critical theory, Arte Povera may exist on the fringes of pedagogical objectives that underline a rationalistic attitude to learning and climax in standardizing (Eisner, 2005) how Italian language is taught. Conceivably, in this space of didactic discussion, Arte Povera can make its most unique impact. Arte Povera demands we defy patterns of traditional belief and contemplate why we live. In the Italian-language classroom, Arte Povera pursues different answers to critical individual, ecological, and social issues that involve imaginative, inventive answers. Surrounded by a critical pedagogy of place, it produces occasions for learners to imagine, learn language, and ponder crucial issues about language, culture, and ecology. Establishing Italian-language pedagogy in a critical pedagogy of the arts converges concepts and materials that deepen the Italian cultural and linguistic understandings and link them to crucial concerns.

In modern life and pedagogy, social ideas often are sidelined in favor of consumption economies. However, problematical questions of culture, ecology, society, and language are becoming progressively more crucial to the future of learners' lives. They require a methodology that expands the learning functions to incorporate questions of social and eco-justice. Arte Povera can inform learners of Italian language about distinctive aspects of the Italian environment and culture. It offers opportunities to involve Italian-language 
learners into important modern concerns and relate their learning to natural communities (Graham, 2007). Arte Povera in the Italian-language classroom can shift from the vital but restrictive notion of art toward a vision of teaching that engages students in a reflective social process with the Italian environment and culture through language acquisition.

\section{References}

Abednia, A. (2015). Practicing critical literacy in second language reading. International Journal of Critical Pedagogy, 6, 77-94.

Abrantes de Andrade, E. M. (2006). Improving how listening skills are taught in the EFL classroom. Unpublished master's thesis. Universidade de Cabo Verde.

Adorno, T. W. (2007). Prisms. MIT Press.

Alter, F. (2011). Exploring visual arts pedagogies that support critical and creative thinking. Australian Art Education, 34(1), 10-29.

Bamisile, S. A. (2008). Sociocultural commitment in things fall apart. Africana Studia, 11(1), 247-264.

Bennett, C. (2008). Substantive thoughts? The early work of Alighiero Boetti. October, 124, 75-97. https://doi.org/10.1162/octo.2008.124.1.75

Bottinelli, S. (2015). The discourse of modern nomadism: The tent in Italian art and architecture of the 1960s and 1970s. Art Journal, 74(2), 62-80. https://doi.org/10.1080/00043249.2015.1095540

Breidbach, S., Medina, J., \& Mihan, A. (2014). Critical literacies, multiliteracies and foreign language education. In C. Koenings, F. Knester, \& L. Gnutzmann (Eds.), Fremdspachen Lehren und Lernen (pp. 91-106). Narr Verlag.

Cardona, L., Rico, C., \& Sarmiento, S. (2015). Developing cultural awareness: The text-driven approach as evidence of a good language teaching practice. Creative Education, 6 , 1360-1385.

Celant, G. (1967). Appunti per una guerriglia. Flash Art, 5, 1.

Celant, G. (2008). Artmix: Flussi tra arte, architettura, cinema, design, moda, musica e televisione. Milano: Feltrinelli.

Chomsky, N. (2015). Aspects of the theory of syntax (50th ed). MIT Press.

Christov-Bakargiev, C. (2014). Arte Povera. Phaidon.

Crookes, G. (2009). The practicality and relevance of second language critical pedagogy. Language Teaching, 43, 333-348. https://doi.org/10.1017/S0261444809990292

Crookes, G. (2020). Critical pedagogy in language teaching. In L. Ortega (Ed.), The encyclopedia of applied linguistics. Wiley/Blackwell. 


\section{I Macrothink}

International Journal of Linguistics

ISSN 1948-5425

2020, Vol. 12, No. 4

Cullinan, N. (2008). From Vietnam to Fiat-Nam: The politics of arte povera. October, 124, 8-30.

Cullinan, N. (2011). Arte povera: Linz, London, Rome, Leeds and Venice. Burlington Magazine, 153, 758-760.

Degener, S. C. (2001). Making sense of critical pedagogy in adult literacy education. In J. Comings, B. Garner, \& C. Smith (Eds.), Annual Review of Adult Learning and Literacy (Vol. 2, pp. 26-62). Jossey-Bass.

Diez, R. (2009). Arte povera. Arte, 14-17.

Drakouli, A., Mamidaki, S., \& Tsatalbassoglou, A. I. (2013). On teaching Italian language in Greece. Annals of the University of Craiova, 35, 220-236.

Duncum, P. (2010). Seven principles for visual culture education. Art Education, 63, 6-10.

Eisner, E. (2005). Opening a shuttered window: An introduction to a special section on the arts and the intellect. Kappan, 87, 14-18. https://doi.org/10.1177\%2F003172170508700104

Emmison, M., \& Smith, P. (2000). Researching the visual: Images, objects, contexts and interactions in social and cultural inquiry. Sage.

Farias, M. (2005). Critical language awareness in foreign language learning. Literatura y Lingüística, 16, 211-222. https://doi.org/10.4067/S0716-58112005000100012

Farokhi, M., \& Hashemi, M. (2012). The impact/s of using art in English language learning classes. Procedia: Social and Behavioral Sciences, 31, 923-926. https://doi.org/10.1016/j.sbspro.2011.12.170

Formato, G. (2018). Instilling critical pedagogy in the Italian language classroom. Journal of Language Teaching and Research, 9, 1117-1126. https://doi.org/10.17507/jltr.0906.01

Freire, P. (2000). Pedagogy of the oppressed (30th ed.). Continuum.

Freire, P. (2005). Education for critical consciousness. Continuum.

Freire, P., \& Macedo, D. P. (2016). Literacy: Reading the word and the world. Routledge.

Galimberti, J. (2012). The intellectual and the fool: Piero Manzoni between the Milanese art scene and the land of Cockaigne. Oxford Art Journal, 35, 75-93. https://doi.org/10.1093/oxartj/kcs004

Garcia, L.-G. (2015). Empowering students through creative resistance: Art-based critical pedagogy in the immigrant experience. Diálogo, 18, 139-149. https://doi.org/10.1353/dlg.2015.0037

Gilman, C. (2008). Pistoletto's staged subjects. October, 124, 53-74. https://doi.org/10.1162/octo.2008.124.1.53

Giroux, H. A. (2001). Theory and resistance in education: Towards a pedagogy for the opposition. Bergin \& Garvey. 


\section{Macrothink}

International Journal of Linguistics

ISSN 1948-5425

2020, Vol. 12, No. 4

Giroux, H. A. (2005). Border crossings: Cultural workers and the politics of education. Routledge.

Giroux, H. A. (2011). On critical pedagogy. Continuum.

Giroux, H. A. (2016). Schooling and the struggle for public life: Democracy's promise and education's challenge. Routledge.

Graham, M. A. (2007). Art, ecology, and art education: Locating art education in a critical placed-based pedagogy. Studies in Art Education, 48, 375-391. https://doi.org/10.1080/00393541.2007.11650115

Gramsci, A. (2014). Selections from the prison notebooks of Antonio Gramsci. International.

Gramsci, A., \& Rosengarten, F. (2011). Letters from prison. Columbia University Press.

Greene, M. (2018). Landscapes of learning. Teachers College Press.

Gude, O. (2007). Principles of possibility: Considerations for a 21st century art and culture curriculum. Art Education, 60, 6-17. https://doi.org/10.1080/00043125.2007.11651621

Hamilton, J. (2008). Making art matter: Alberto Burri's Sacchi. October, 124, 31-52. https://doi.org/10.1162/octo.2008.124.1.31

Hawkins, M., \& Norton, B. (2009). Critical language teacher education. In A. Burns, \& J. Richards (Eds.), Cambridge guide to second language teacher education (pp. 30-39). Cambridge.

Hayes, C. (2020). The art of portraiture: An urban school art teacher's use of art as creative resistance. In R. Papa (Ed.), Handbook on promoting social justice in education. Springer.

Held, D. (2006). Introduction to critical theory: Horkheimer to Habermas. University of California Press.

Hogan, M. (2006). Implementing critical inquiry in arts responding classes: Studies of teaching strategies whilst studying contemporary art works. Unpublished master's thesis. University of Melbourne.

Horkheimer, M., \& O'Connell, M. J. (2002). Critical theory: Selected essays. Continuum.

Horkheimer, M., Adorno, T. W., \& Schmid Noerr, G. (2002). Dialectic of enlightenment: philosophical fragments. Stanford University Press.

Johnson, S. M., \& Randolph, L. J. Jr. (2015). Critical pedagogy for intercultural communicative competence: Getting started. Language Educator, 10(3), 36-39.

Kalekin-Fishman, D., \& Langman, L. (2015). Alienation: The critique that refuses to disappear. Current Sociology, 63, 916-933. https://doi.org/10.1177\%2F0011392115591612

Krashen, S. (2003) Explorations in language acquisition and use: The Taipei lectures. Heinemann. 


\section{I Macrothink}

International Journal of Linguistics

ISSN 1948-5425

2020, Vol. 12, No. 4

Krauss, R. (2008). Giovanni Anselmo: Matter and monochrome. October, 124, 125-136. https://doi.org/10.1162/octo.2008.124.1.125

Leavy, P. (2009). Method meets art: Arts-based research practice. Guilford Press.

Lincoln, Y. S., \& Guba, E. G. (2000). Paradigmatic controversies, contradictions, and emerging confluences. In N. K. Denzin, \& Y. S. Lincoln (Eds.), Handbook of qualitative research (2nd ed., pp. 163-188). Sage.

Malloy, J. (2003). Women, art, and technology. MIT Press.

Mansoor, J. (2001). Piero Manzoni: "We want to organize disintegration". October, 95, 29-53.

McKee, B. (2013). Slow forces. Landscape Architecture, 103, 108-113.

Merriam, S. B., Tisdell, E. J., Merriam, S. B., \& Merriam, S. B. (2016). Qualitative research: A guide to design and implementation. Jossey-Bass.

Mezirow, J. (2000). Transformative dimensions of adult learning. Jossey-Bass.

Moeller, A., \& Fatlin Osborn, S. R. (2014). A pragmatist perspective on building intercultural communicative competency: From theory to classroom practice. Foreign Language Annals, 47, 669-683. https://doi.org/10.1111/flan.12115

Nietzsche, F. W. (2015). The use and abuse of history. Martino. Original published 1876.

Peters, C. (2016). Critical pedagogy and art. In M. A. Peters (Ed.), Encyclopedia of educational philosophy and theory. Springer.

Pinkus, K. (2009). Dematerialization: From arte povera to cybermoney through Italian thought. Diacritics, 39(3), 63-75. https://doi.org/10.1353/dia.2009.0025

Rancière, J. (2000). What aesthetics can mean. In P. Osborn (Ed.), From an aesthetic point of view. Serpant's Tail.

Rancière, J. (2010). Dissensus: On politics and aesthetics. Continuum.

Randolph, L. J. Jr., \& Johnson, S. M. (2017). Social justice in the language classroom: A call to action. In S. M. Johnson, \& P. Garrett-Rucks (Eds.), Dimension (pp. 99-121). 2018 Joint Conference of the Southern Conference on Language Teaching. Retrieved from http://www.scolt.org/wp-content/uploads/2019/08/SCOLT-Dimension-2018_FINAL.pdf

Rashidi, N., \& Safari, F. (2011). A model for EFL materials development within the framework of critical pedagogy (CP). English Language Teaching, 4, 250-259.

Reagan, T. (2006). The explanatory power of critical language studies: Linguistics with an attitude. Critical Inquiry in Language Studies, 3, 1-22. https://doi.org/10.1207/s15427595cils0301_1

Reagan, T., \& Osborn, T. (2002). The foreign language educator in society: Toward a critical pedagogy. Lawrence Erlbaum Associates. 


\section{Macrothink}

International Journal of Linguistics

ISSN 1948-5425

2020, Vol. 12, No. 4

Román, M. (2005). Sociedad del conocimiento y refundación de la escuela desde el aula. EOS.

Sandmire, D. A., Rankin, N. E., Gorham, S. R., Eggleston, D. T., French, C. A., Lodge, E. E., ... Grimm, D. R. (2016). Psychological and autonomic effects of art making in college-aged students. Anxiety, Stress, and Coping, 29, 561-569. https://doi.org/10.1080/10615806.2015.1076798

Stebaieva, O. (2018). An international perspective on teaching Italian language and culture. Zhytomyr Ivan Franko State University Journal Pedagogical Sciences, 3(94), 5-9. https://doi.org/10.35433/pedagogy.3(94).2018.5-9

Strickland, P. (2008). Teachers arts education: Integrating arts in the classroom. Doctoral dissertation, Gonzaga University, ProQuest Dissertations and Theses Global.

Timuçin, M., \& Aryoubi, H. (2016). Integrating arts in EFL curricula: A focus on language listening skills. International Journal of Languages' Education and Teaching, 4, 233-256.

Trend, D. (2012). Henry Giroux and the arts. Policy Futures in Education, 10, 616-621. https://doi.org/10.2304\%2Fpfie.2012.10.6.616

Veikos, C. (2006). To enter the work: Ambient art. Journal of Architectural Education, 59(4), 71-80. https://doi.org/10.1111/j.1531-314X.2006.00056.x

Vergine, L. (2001). Art on the cutting edge: A guide to contemporary movements. Skira.

Williams, R. (1967). Preface to the second edition. Communications. Barnes \& Noble.

Žemberová, I. (2014). Art in foreign language education. Journal of Language and Cultural Education, 2, 240-253.

\section{Copyrights}

Copyright for this article is retained by the author(s), with first publication rights granted to the journal.

This is an open-access article distributed under the terms and conditions of the Creative Commons Attribution license (http://creativecommons.org/licenses/by/4.0/) 